\title{
CONFERENCE PROCEEDING
}

The Aryan Jesus:

\section{Christian Theologians and the Bible in Nazi Germany}

\author{
Susannah Heschel, Dartmouth College \\ Kevin P. Spicer, Stonehill College
}

Presented at the Center for Christian-Jewish Learning,

Boston College, April 12, 2010

On April 12, 2010, following the April $11^{\text {th }}$ observance of Holocaust Remembrance Day, Susannah Heschel addressed the theme of her 2008 book, The Aryan Jesus: Christian Theologians and the Bible in Nazi Germany. Heschel's book examines the membership and activities of the Institute for the Study and Eradication of Jewish Influence on German religious Life. Based on years of archival research, Heschel shows that during the Third Reich this Institute became the most important propaganda organ of German Protestantism, exerting a widespread influence and producing a nazified Christianity that placed antisemitism at its theological center. Members of the Institute formed a community of like-minded Nazi Christians who remained active in Germany's post-war years.

Kevin Spicer, C.S.C., associate professor of history at Stonehill College, responded to Heschel's remarks with a discussion of several German theologians who attempted to adapt Catholic teachings to National Socialism during the Nazi regime.

View the video of Susannah Heschel's presentation and Kevin Spicer's response: http://frontrow.bc.edu/program/heschel 